\title{
Perkembangan Fisik-Motorik Siswa Usia Dasar: Masalah dan Perkembangannya
}

Suyadi, Wina Calista, Deska Puspita, Pascasarjana Fakultas Ilmu Tarbiyah dan Keguruan Universitas Islam Negeri Sunan Kalijaga Yogyakarta e-mail: yadi.uinjogja@gmail.com; winacalista21@gmail.com; puspitadeska@gmail.com

\section{ABSTRAK}

Tujuan dalam penelitian ini adalah menganalisis perkembangan fisik-motorik siswa usia dasar yang tidak tercapai. Penelitian ini menggunakan metode kualitatif deskriptif, data diperoleh dengan observasi, wawancara dan dokumentasi.. Penelitian dilakukan di SLB Bakti Kencana I. Sampel dalam penelitian ini adalah satu orang siswa dikelas III yang mengalami kelainan pada proses perkembangan fisik-motorik. Hasil analisis kemudian dianalisis dengan menggunakan kajian teori mengenai perkembangan fisik-motorik siswa yang tidak tercapai. Hasil penelitian menunjukkan bahwa perkembangan fisik-motorik siswa yang tidak tercapai disebabkan karena siswa mengalami kelainan genetik (down syndrome) . Down syndrome adalah kelainan genetik yang disebabkan kerena kelebihan kromosom 21 atau trisomy 21 yang menyebabkan keterbatasan fisik, motorik, serta intelektual, dan sering terjadi dengan insidensi 1:1000 kelahiran yang salah satunya berakibat lemahnya otot pada salah satu tangan sehingga siswa sulit melakukan gerakan seperti menulis, menggambar serta aktifitas sehari-hari. Pembelajaran didalam kelas disesuaikan dengan minat belajar siswa. Adapun tujuan utama dalam pembelajaran untuk anak-anak yang memiliki perkembangan fisik motorik yang tidak tercapai (down syndrome ) yaitu melatih kemandirian anak dan interaksi sosial dalam lingkungan sekitar.

Kata Kunci : Perkembangan, Fisik-Motorik, Tidak Tercapai

\section{A. PENDAHULUAN}

Perkembangan fisik,motorik diartikan sebagai perkembangan dari unsur kematangan dan pengendalian gerak tubuh. Perkembangan fisik memiliki peran yang sangat penting bagi kehidupan anak, baik secara langsung maupun tidak langsung. Secara langsung perkembangan fisik seorang anak akan menentukan keterampilan anak dalam bergerak. Sementara secara tidak langsung, pertumbuhan dan perkembangan fisik akan mempengaruhi cara pandang anak terhadap dirinya sendiri dan cara pandang anak terhadap orang lain, perkembangan fisik berjalan seiring dengan perkembangan motorik. 
Dalam proses perkembangannya, perkembangan fisik akan mempengaruhi kemampuan motorik. Perkembangan fisik lazimnya ditandai dengan perubahan pada tinggi dan berat badan, serta bentuk tubuh dan juga perkembangan otak. Jika perkembangan fisik anak berkembang dengan baik tentu akan berpengaruh pada keterampilan motoriknya. Begitupun dengan anak yang perkembangan fisiknya mengalami gangguan, akan berdampak pada terganggunya kemampuan motorik anak tersebut. Gangguan fisik dan motorik anak yang mengalami kelainan atau cacat yang menetap pada alat gerak (tulang) sedemikian rupa sehingga memerlukan pelayanan pendidikan khusus. Untuk mengatasai gangguan perkembangan sejak dini diperlukan pemeriksaan yang diawali sejak dalam kandungan serta asupan gizi yang harus diperhatikan. Adapun hal yang dapat dilakukan agar manjadikan keterbatasan tersebut bukan suatu kekurangan yaitu memberikan motivasi dan pendidikan bagi penyandang keterbatasan fisik dan lainya agar mereka mempunyai kemampuan selayaknya orang yang memiliki perkembangan secara normal.

Gangguan perkembangan fisik motorik pada usia anak sekolah dasar menjadi kendala tersendiri dalam aktifitas anak diantaranya anak kesulitan bermain, menulis, menghapus papan tulis dan lain sebagain4ya. Layaknya usia 6-12 tahun pada anak sekolah dasar mereka sudah mampu melakukan kegiatan fisik motorik seperti menulis, menggambar, mewarnai, berlari, melompat dan lain sebagainya.Dalam penanganan kasus diatas maka diperlukan kerjasama yang baik antara pemerintah sebagai pihak yang menjamin hak-hak yang sama pada setiap manusia untuk mendapat pendidikan yang layak, guru sebagai tenaga pendidik yang memberikan pendidikan, mengajarkan ilmu dan sebagai motivasi siswa agar memiliki semangat belajar yang tinggi serta orang tua sebagai orang yang memiliki peran utama dalam memberikan pendidikan dirumah.

Berdasarkan uraian permasalahan diatas untuk mengetahuai secara mendalam tentang gangguan perkembangan fisik motorik siswa pada usia sekolah dasar dalam artikel ini akan dibahas tentang gangguan perkembangan fisik motorik yang tidak tercapai pada usia sekolah dasar di SLB dengan tujuan untuk mengetahui bagaimana proses pembelajaran yang dilakukan disekolah terhadap siswa yang 
mengalami gangguan perkembangan fisik motorik. Harapannya guru dapat membelajarkan siswa dengan sebaik mungkin meski keterbatasan fisik yang dimiliki oleh siswa menjadi kendala terbesar bagi siswa dalam proses pembelajaran.

\section{B. Metode Penelitian}

Penelitian yang digunakan adalah penelitian deskriptif (descriptive research) yaitu suatu metode penelitian yang ditujukan untuk menggambarkan fenomena yang ada, yang berlangsung pada saat ini atau saat yang lampau. Penelitian ini tidak mengadakan manipulasi atau pengubahan pada variabel bebas, tetapi menggambarkan suatu kondisi apa adanya. (Sukmadinata, 2006) Pendekatan yang digunakan dalam penelitian ini yaitu pendekatan kualitatif. Informasi didapat melalui observasi, wawancara dan dokumentasi yang dilakukan untuk menjawab permasalahan yang memerlukan pemahaman secara mendalam. Informasi yang dikumpulkan dalam penelitian ini mengenai kemandirian anak down syndrome usia sekolah dasar. Data yang diperoleh bersifat deskriptif yang berhasil dihimpun dari beberapa sumber. Subjek penelitian merupakan benda, hal atau orang tempat variabel melekat. (Arikunto, 2010) Dalam penelitian ini subjek yang ditentukan yaitu: Siswa down syndrome, guru dan orang tua/ wali dari anak down syndrome. Muhammad Ainur Rofiq siswa kelas III selaku subjek dalam penelitian, dan wali dari Muhammad Ainur Rofiq, serta Ibu Ristanti selaku walikelas III.

Penelitian ini dilakukan pada pada hari Rabu ,24 Oktober 2018 di SLB Baksi Kencana 1 yang terletak di jalan Berbah-Krikilan,Tegaltirto, Kabupaten Sleman, Yogyakarta. Teknik pengumpulan data yang digunakan dalam penelitian ini adalah wawancara, observasi, dan dokumentasi. Teknik analisis data didalam penelitian ini yaitu analisis sebelum kelapangan, analisis dilapangan dengan model Miles and Hubermen yang meliputi reduksi data, data display dan conclusion drawing. Adapun populasi dalam penelitian ini adalah seluruh siswa dikelas III. Sedangkan yang sampel dalam penelitian ini yaitu satu siswa dikelas III yaitu Muhammad Ainur Rofiq yang menjadi subjek dalam penelitian ini.

\section{Hasil Penelitian Dan Analisis}


Berdasarkan hasil penelitian yang telah dilakukan dilapangan diperoleh data bahwa siswa yang menjadi subjek penelitian yaitu siswa yang bernama Muhammad Ainur Rofiq. Rofiq merupakan siswa yang mengalami gangguan dalam perkembangan fisik motorik yang disebabkan karena kelainan genetik atau lebih dikenal dengan istilah Down Syndrome. Ada beberapa hal yang menjadi kendala Rofiq dalam beraktifas diantaranya yaitu: 1) Fungsi tangan yang tidak dapat bekerja sama dengan baik karena mengalami kelayuan pada otot, sehingga segala aktifitas lebih mengutamakan tangan kiri, 2) Tidak dapat memegang, menyentuh, menggambar, dan lain sebagainya dengan sempurna, 3) Gerak motorik tidak sempurna, sehingga susah menulis, menggambar, dan mewarnai sesuai dengan garis, 4) Melakukan gerakan reflex dengan orang lain (misal memukul dengan tidak sengaja), 5) Kurang menyukai kegiatan yang sifatnya melibatkan semua gerakan fisik, karena subjek mudah lelah dalam beraktivitas.

Berdasarkan hasil wawancara dengan wali kelas III yaitu dengan Ibu Ristanti diperoleh informasi bahwa tujuan akhir dari sebuah pembelajaran di SLB yaitu mengarahkan anak untuk dapat bersikap mandiri terhadap diri sendiri dan sikap sosial terhadap lingkungan. Sehingga untuk ranah kognitif tidak menjadi hal utama yang harus dicapai dalam pembelajaran. Ada beberapa hal yang menjadi harapan dari sebagian besar orang tua yang memiliki anak berkebutuhan khusus di SLB yaitu anak menjadi mandiri atau mengontrol dirinya sendiri, serta dapat bersosialisasi dengan baik dilingkungan sekitar. Proses pembelajaran dikelas guru hanya menyesuaikan minat siswa dalam belajar sehingga materi pelajaran tidak bersifat baku.

Selain pembelajaran di kelas, observasi juga dilakukan di luar kelas pada saat kegiatan olah raga. program pendidikan olah raga yang rutin dan teratur dilaksanakan setiap seminggu sekali yaitu pada hari rabu. olah raga sangat penting dilakukan untuk merangsang perkembangan fisik motorik siswa. agar aktivitas olah raga memberikan rangsangan yang tepat, maka jenis-jenis kegiatan olah raga yang ada di SLB disesuaikan dengan tahap perkembangan dan kebutuhan fisik siswa. Program olah raga yang cocok diselenggarakan antara lain memberikan kesempatan kepada anak untuk melakukan kegiatan secara aktif, dan untuk 
mengimplementasikan permainan-permainan motorik yang sesuai dengan kebutuhan siswa. Dengan demikian diharapkan siswa senang dalam berolah raga, melalui permainan yang dirancang sesuai dengan tahap perkembangan untuk melatih fisik motorik siswa

Adapun dalam pembelajaran olahraga berdasarkan hasil observasi di lapangan, siswa diberikan latihan-latihan dasar yang melibatkan seluruh fisikmotorik seperti dimulai dengan berlari bersama mengelilingi lapangan dan kemudian dilanjutkan dengan berlatih menendang bola, melempar bola dan menangkap bola. Hal tersebut bertujuan untuk merangsang kerja fisik agar lebih baik. Berdasarkan hasil wawancara dengan wali murid dari Muhammad Ainur Rofiq bahwa gelaja awal mula sebelum terdeteksi Down Syndrome pada saat umur delapan bulan Rofiq mengalami kejang-kejang atau step yang kemudian berdampak pada perkembangan yang dialami kurang sempurna. Selanjutnya pada kelas II Rofiq kembali mengalami sakit yang menyebabkan koma atau tidak sadarkan diri dirumah sakit selama berminggu-minggu. Hal itu yang menyebabkan banyak perubahan yang terjadi diantaranya yaitu cenderung pendiam dan tidak peduli dengan lingkungan sekitar.

\section{Perkembangan Fisik Anak Usia Sekolah Dasar}

Perkembangan fisik menurut hukum Cephalocaudal yaitu pertumbuhan dimulai dari kepala kearah kaki, kepala tumbuh lebih dahulu daripada bagian lainnya (pada pertumbuhan prenatal, janin), bayi lebih dahulu mempergunakan mulut dan matanya lebih cepat daripada anggota geraknya. Tugas perkembangan fisik anak usia 6-12 tahun yaitu belajar kemampuan fisik yang diperlukan agar bisa melaksanakan permainan atau olahraga, membentuk sikap tertentu terhadap dirinya sebagai pribadi yang sedang tumbuh dan berkembang, belajar bergaul dengan teman-teman seumurnya, mengembangkan kemampuan dasar dalam membaca, menulis dan menghitung, mengembangkan nurani, moralitas dan skala nilai, memperoleh kebebasan pribadi, membentuk sikap terhadap kelompok sosial dan instusi. (Fahami, 2014) Adapun kategori keterampilan fisik menurut (Hurlock, 1997) yaitu 1) keterampilan menolong diri sendiri, 2) keterampilan dalam menolong orang lain, 3) Keterampilan dalam beraktifitas disekolah, 4) 
Keterampilan Bermain. Apabila fisik mengalami gangguan atau hambatan dalam perkembangannya, maka kemampuan motorik pun akan ikut terhambat. Perkembangan fisik individu meliputi empat aspek yaitu sistem syaraf, otot, kelenjar endokrin, dan struktur tubuh atau fisik. Sistem syaraf sangat mempengaruhi perkembangan kecerdasan dan emosi. Otot-otot mempengaruhi perkembangan kekuatan dan kemampuan motorik. Kelenjar endokrin menyebabkan munculnya tingkah laku baru. Struktur fisik atau tubuh meliputi tinggi, berat, dan proporsi. Aspek fisik yang paling penting adalah otak sebagai pusat atau sentral perkembangan dan fungsi perkembangan. Otak mempunyai pengaruh yang sangat menentukan bagi perkembangan individu lainnya. Berkaitan dengan hal tersebut terdapat beberapa jenis gangguan fisik pada anak yaitu gangguan pancaindra, obesitas, stereotipik, malnutrisi dan cacat tubuh.

Bagi anak-anak usia sekolah dasar perkembangan fisik merupakan hal yang sangat penting, karena akan mempengaruhi perilaku mereka sehari-hari,termasuk perilaku dalam belajar. Perkembangam fisik yang dimiliki oleh masing-masing akan mempengaruhi persepsi mereka pada dirinya sendiri dan orang lain. Artinya anak-anak yang memiliki fisik yang ideal akan lebih percaya diri dan anak-anak yang memiliki kondisi fisik yang berbeda akan tidak percaya diri terhadap lingkungan.

\section{Perkembangan Motorik Anak Usia Sekolah Dasar}

Perkembangan motorik merupakan perkembangan pengendalian jasmani melalui kegiatan pusat syaraf, urat syaraf, dan otot yang terkoordinasi. (Aghnaita, 2017) Seorang anak usia 6 tahun yang bangun tubuhnya sesuai untuk usia tersebut, akan dapat melakukan hal-hal yang lazim dilakukan oleh anak berumur 6 tahun. (Hurlock, 1997) Gerakan-gerakan yang dilakukan oleh anak-anak termasuk anak sekolah dasar merupakan koordinasi dari beratus-ratus otot yang unik. Keterampilan motorik dapat dikelompokkan menurut ukuran otot-otot dan bagian badan yang terkait, yaitu keterampilan motorik kasar dan halus. Motorik kasar meliputi keterampilan otot-otot besar lengan, kaki, batang tubuh seperti berjalan, melompat, berlari. (Upton, 2012). Sedangkan keterampilan motorik halus meliputi 
otot-otot kecil yang ada diseluruh tubuh, seperti menyentuh, memegang, menulis, dan menggambar. Keterampilan motorik bagi anak sekolah dasar merupakn suatu aktivitas yang menyenangkan, hal ini disebabkan otot-otot mereka mulai menemukan fungsinya atau berkembang. Sehingga mereka tidak dapat duduk diam dalam waktu lama. (Murti, 2018)

Perkembangan motorik pada anak usia sekolah dasar menurut (Desmita, 2012) yaitu 1) Mulai usia 6 tahun sudah berkembang koordinasi antara mata dan tangan (visio motoric) yang dibutuhkan untuk membidik, menyepak, melempar, dan menangkap, 2) Usia 7 tahun, tangan anak semakin kuat dan anak lebih menyukai menggunakan pensil daripada krayon untuk melukis, 3) Usia 8 sampai 10 tahun, anak dapat menggunakan tangan secara bebas, mudah, dan tepat. Koordinasi motorik halus berkembang, sehingga anak dapat menulis dengan baik, ukuran huruf menjadi lebih kecil dan rata, 3) Usia 10 sampai 12 tahun, anak-anak mulai memiliki keterampilan keterampilan manipulatif menyerupai kemampuan orang dewasa. Mereka mulai menampilkan gerakan-gerakan kompleks, rumit, dan cepat yang diperlukan untuk menghasilkan karya kerajinan yang berkualitas atau memainkan alat musik tertentu.

Perkembangan motorik yang terlambat berarti perkembangan motorik yang berada di bawah normal umur anak. Akibatnya pada umur tertentu anak tidak menguasai tugas perkembangan yang diharapkan oleh kelompok sosialnya. Sebagai contoh anak yang berada di bawah normal mengalami kesulitan untuk dapat berjalan dan makan sendiri akan dipandang sebagai anak yang "terbelakang". Banyak penyebab terlambatnya perkembangan motorik salah satunya timbul dari kerusakan otak anak pada waktu lahir atau kondisi pralahir yang tidak menguntungkan atau lingkungan yang tidak menyenangkan pada permulaan pascalahir. Akan tetapi keterlambatan lebih sering disebabkan oleh kurangnya kesempatan untuk mempelajari keterampilan motorik, perlindungan orang tua yang berlebihan atau kurangnya motivasi anak untuk mempelajari keterampilan motorik. (Hurlock, 1997) Tidak banyak orangtua yang mengerti bahwa keterampilan motorik kasar dan halus seorang anak perlu dilatih dan dikembangkan setiap saat dengan berbagai aktivitas. Pengembangan ini memungkinkan seorang anak 
melakukan berbagai hal dengan lebih baik, termasuk di dalamnya pencapaian dalam hal akademis dan fisik. Perkembangan motorik meliputi motorik kasar dan motorik halus.

Gerakan motorik kasar merupakan salah satu kemampuan keterampilan gerak dasar yang penting untuk perkembangan aspek sosial anak. (Malik, 2014) Motorik kasar adalah gerakan tubuh yang menggunakan otot - otot besar atau sebagian besar atau seluruh anggota tubuh yang dipengaruhi oleh kematangan anak itu sendiri, misalnya kemampuan untuk duduk, menendang, berlari dan lainnya, sedangkan motorik halus adalah gerakan yang menggunakan otot halus atau sebagian anggota tubuh tertentu yang dipengaruhi oleh kesempatan untuk belajar dan berlatih, misalnya memindahkan benda dari tangan, mencoret, menyusun, menggunting, dan menulis.

\section{Gangguan Perkembangan Fisik-Motorik Anak Usia Sekolah Dasar}

Masalah yang sering timbul dalam pertumbuhan dan perkembangan anak usia sekolah dasar salah satunya yaitu gangguan pertumbuhan fisik dan perkembangan motorik anak. Perkembangan fisik dan motorik anak yang tidak tercapai dapat diartikan bahwa perkembangan fisik dan motorik anak tersebut mengalami gangguan.Ciri-ciri dari gangguan fisik dan motorik anak usia sekolah dasar yaitu mengalami kelainan atau cacat yang menetap pada alat gerak (tulang, sendi, otot). Menurut Syamsu Yusuf bahwa salah satu yang menyebabkan perkembangan fisik motorik mengalami gangguan disebabkan karena kekurangan gizi pada ibu hamil yang mengakibatkan berat badan bayi sangat rendah (berkaitan erat dengan angka kematian yang tinggi), dan perkembangan yang buruk. (Yusuf, 2014)

Down syndrome dapat dideteksi melalui pemeriksaan dan pengujian antenatal. Pemeriksaan antenatal digunakan untuk melihat hal tidak normal yang berkembang selama kehamilan. Jika dalam pemeriksaan ini dinyatakan kemungkinan cukup tinggi janin terkena down syndrome maka dilakukan tes diagnosis karenanya pemeriksaan kesehatan rutin pada ibu hamil wajib dilakukan untuk mengurangi resiko anak lahir dengan down syndrome. (Kawanto, 2010) 
Berdasarkan hasil observasi dilapangan bahwa siswa yang menjadi subjek dalam penelitian mengalami perkembangan fisik-motorik siswa yang tidak tercapai disebabkan penyimpangan genetik atau Down syndrome yang menyebabkan kesulitan dalam beraktifitas disekolah. Down syndrome adalah salah satu gangguan yang menyerang perkembangan fisik motorik anak. down syndrome sendiri merupakan kelain kromosom, yaitu terbentuknya kromososm 21 (trisomy 21) akibat kegagalam sepasang kromosom untuk saling memisahkan diri saat terjadi pembelahan. Anak yang mengalami down syndrome biasanya kurang bisa mengkoordinasikan antara motorik kasar dan halus. Misalnya kesulitan mengenakan pakaian yang berkancing, dan memasang sepatu yang bertali secara mandiri. (Rina, 2016) Penderita down syndrome biasanya ditandai dengan bentuk fisik yang berbeda seperti wajah yang cenderung rata terutama pada batang hidung diantara kedua mata, telinga kecil, postur dan bentuk tubuh lebih pendek, mulut kecil dan lidah tampak menjulur, leher pendek, tangan yang tidak sempurna seperti panjang tangan dan kaki lebih pendek ,otot dan sendi kurang kuat atau layu. (Cahyani, 2018).

Berdasarkan ciri-ciri diatas dapat diketahui bahwa dampak dari down syndrome yang dialami oleh subyek yaitu otot dan sendi yang lemah (layu). Salah satu bagian tubuh subjek yang mengalami kelayuan pada otot dan sendi terletak pada bagian tangan, dimana hanya tangan kiri yang berfungsi untuk melakukan gerakan, lazimnya gerakan atau aktivitas anak secara normal dapat melibatkan kedua gerakan tangan dengan baik. Berkaitan dengan penyimpangan genetik yang menyebabkan kelayuan otot atau sendi yang mempengaruhi pergerakan anak dalam beraktivitas sehari-hari termasuk proses kegiatan belajar di sekolah yaitu seperti 1) pergerakan tangan yang tidak stabil "gemetar" 3) lambatnya menulis, 3) kesulitan dalam menggambar, 4) Kesulitan dalam mewarnai objek gambar sesuai bidang gambar, 5) siswa mudah kelelahan dalam beraktivitas, 6) sering melakukan gerakan refleks dengan orang lain (memukul dengan tidak sengaja).

Pola Pembelajaran Anak Dengan Perkembangan Fisik Motorik Yang Tidak Tercapai 
Masalah perkembangan belajar anak yang mengalami perkembangan fisik motorik yang tidak tercapai down syndrome secara keseluruhannya mengalami keterbelakangan perkembangan. Pada pertumbuhannya mengalami masalah lambat dalam semua aspek perkembangan yaitu lambat untuk berjalan, menulis , perkembangan motorik halus, perkembangan sosial, dan perkembangan motorik kasar yang lambat yang disebabkan otot-otot yang lemah.

Dalam penelitian ini merupakan anak yang memiliki gangguan fisik motorik disebabkan karena down syndrome. Dalam proses pembelajaran dikelas subjek mengalami beberapa kendala diantaranya, siswa dapat menulis akan tetapi membutuhkan waktu yang lama, sulit menggambar dan tidak bisa mewarnai suatu gambar dengan rapi. Dalam pembelajaran olahraga subjek cenderung memiliki motivasi yang rendah karena subjek memiliki daya tahan tubuh yang lemah dan mudah lelah. Selain itu anak dengan down syndrome cenderung mengalami keterlambatan dalam menjalankan fungsi adatifnya dan berinteraksi dengan lingkungan sosial Keadaan inilah yang mempengaruhi dalam ketercapaian aspek kemandirian pada anak tersebut. Namun, hal itu bukan berarti anak dengan down syndrome tidak mampu mandiri. Mereka tetap bisa mencapai kemandiriannya, hanya saja berbeda konteks dengan kemandirian anak normal pada umunya.

Terkait dengan uraian diatas seorang guru hendaknya benar-benar memberikan perhatian yang cukup terhadap aspek perkembangan fisik motorik anak. Perhatian disini bukan sekedar untuk kepentingan perkembangan dan aktifitas belajar. Pemahaman guru tentang karakteristik perkembangan fisik motorik akan membawa dampak pada proses pembelajaram disekolah. Adapun kompetensi yang harus dicapai oleh siswa di sekolah luar biasa tentu berbeda dengan sekolah umum. Apabila disekolah pada kurikulum 2013 mencakup tiga ranah yang harus dicapai yaitu kognitif, afektif dan psikomotor. Akan tetapi tujuan di SLB yaitu lebih menanamkan sikap sosial siswa. Sebagaimana menurut hasil wawancara dengan guru wali kelas bahwa pembelajaran di SLB tidak mengutamakan tercapainya kompetensi dari mata pelajaran akan tetapi lebih mengutamakan sikap kemandirian siswa terhadap diri sendiri dan sikap sosial siswa terhadap lingkungan sekitar. Begitupun dengan harapan dari orang tua yang memasukkan anaknya disekolah 
SLB bahwa sebagian besar mereka memiliki harapan agar anaknya dapat mandiri dan percaya diri ketika bersosialisasi dengan lingkungan. Pelayanan dan bimbingan yang diterapkan di SLB bertujuan untuk mendukung pada ketercapaian kemandirian anak.

Kemandirian menjadi aspek yang penting untuk seorang anak, terlebih ketika anak sudah memasuki usia remaja. Namun kemandirian tersebut tidak hanya penting bagi anak normal saja. Anak dengan keterbatasan fisik motorik juga perlu untuk mencapai tingkat kemandiriannya. Dimana walaupun memiliki keterlambatan, namun mereka tetap bisa melakukan aktivitas-aktivitas tertentu oleh diri mereka sendiri dan tidak menggantungkan pada orang lain. (Nadia Uswatun Hasanah, 2014) Seiring dengan sikap kemandirian siswa dalam proses pembelajaran dikelas pun guru juga menyesuaikan minat siswa dalam belajar. Bedanya dengan sekolah umum yang dimana tujuan pembelajaran ditentukan oleh guru. Akan tetapi jika SLB tujuan pembelajaran disekolah menyesuaikan minat siswa. Didalam pembelajaran yang digunakan di kelas tidak terpaku menggunakan strategi pembelajaran secara khusus, akan tetapi guru lebih menyesuaikan minat siswa dalam belajar. Misalnya pada suatu pembelajaran dikelas siswa lebih tertarik untuk belajar mewarnai dalam hal itu guru mengikuti minat siswa untuk mewarnai. Dari hal itu guru melakukan penilaian terhadap hasil mewarnai siswa itu sendiri. Setelah selesai pembelajaran guru akan menyampaikan kepada orang tua hasil belajar siswa dengan tujuan agar orang tua bisa mendidik dan melatih dirumah. Berdasarkan wawancara dengan orang tua subjek bahwa saat dirumah subjek diajarkan menulis, menggambar dan mewarnai.

Sebagaimana menurut guru di kelas bahwa secara umum anak-anak yang memiliki gangguan perkembangan fisik-motorik tidak semuanya diwajibkan untuk mengenyam pendidikan di sekolah luar biasa, mereka bisa memperoleh pendidikan disekolah umum. Secara kognitif, beberapa siswa mampu mencapai tujuan pembelajaran disekolah meskipun mereka lambat dalam prosesnya. Akan tetapi jika dilihat dari aspek psikologis mereka akan terganggu karena mereka akan menjadi ejekan teman-teman disekolah karena mayoritas anak yang disekolah umum merupakan anak yang memiliki perkembangan fisik motori yang normal. 
Layaknya sekolah-sekolah biasa pada umumnya, SLB ini hanya bersifat sementara saja. Kontribusi yang diberikan SLB dalam mendidik anak tidak akan lebih besar dibandingkan pada saat dirumah. Hal ini dikarenakan SLB hanya mampu memberikan pembinaan dan pelayanan bagi peserta didik yang mengalami gangguan dalam perkembangan fisik dalam waktu yang ditentukan (terbatas) sebagaimana para siswa-siswi yang menuntut ilmu di sekolah-sekolah biasa pada umumnya. Untuk selanjutnya mereka dididik dan dibimbing oleh orang tua masing masing dirumah. Dikarenakan waktu yang dihabiskan dirumah akan lebih lama dibandingkan saat di SLB, maka dari itu proses pembelajaran dan pembentukan kemandirian anak akan lebih berperan besar pada saat dirumah.

\section{Kesimpulan}

Perkembangan fisik dan motorik anak yang tidak tercapai dapat diartikan bahwa perkembangan fisik dan motorik anak tersebut mengalami gangguan. Ciriciri dari gangguan fisik dan motorik anak usia sekolah dasar yang ditemukan pada saat melakukan observasi yaitu siswa mengalami gangguan perkembangan pada otot dan sendi yang lemah (layu), hal ini disebabkan karena siswa mengalami Down syndrome yang menyebabkan kesulitan dalam beraktifitas disekolah diantaranya kesulitan dalam menulis, menggambar, dan mewarnai sesuai garis gambar. Adapun tujuan utama dalam pembelajaran untuk anak-anak yang memiliki perkembangan fisik motorik yang tidak tercapai (down syndrome) yaitu melatih kemandirian anak dan interaksi sosial dalam lingkungan sekitar. Untuk mencapai tujuan tersebut dibutuhkan kerjasama antara guru dan orang tua agar meskipun anak-anak memiliki keterbatasan fisik mereka tetapi bisa beraktifitas secara mandiri dan dapat bersosialisasi dengan baik dilingkungan sekitar.

\section{Saran}

Sebagaimana karakteristik pembelajaran yang diterapkan di sekolah luar biasa terhadap anak-anak yang memiliki perkembangan fisik motorik yang tidak tercapai dimana pembelajaran menyesuaikan minat siswa. Untuk itu guru perlu mengembangkan media pembelaran atau alat peraga yang dapat digunakan dalam pembelajaran agar menambah minat siswa dalam belajar.

\section{DAFTAR PUSTAKA}

JIP: Jurnal Ilmiah PGMI.

Volume 4, Nomor 2, Desember 2018

P-ISSN: 2527-4589

Available online at http://jurnal.radenfatah.ac.id/index.php/jip 
Aghnaita. (2017). Perkembangan Fisik Motorik Anak 4-5 Tahun Pada Permendikbud no.137 Tahun 2014 (Kajian Konsep Perkembangan Anak). Al-Athfal: Jurnal Pendidikan Anak, 225.

Arikunto, S. (2010). Manajemen Penelitian. Jakarta: PT.Rineka Cipta.

Cahyani, F. P. (2018). Identifikasi Penyimpangan Tumbuh Kembang Anak Dengan Algoritma Backpropagation. Jurnal Pengembangan Teknologi Informasi dan Ilmu Komputer , 4.

Desmita. (2012). Psikologi Perkembangan. Bandung: PT Remaja Rosdakarya.

Fahami, T. (2014). Proses Tumbuh Kembang Siswa Usia Dasar. Jurnal Pendidikan , 20.

Hurlock, E. B. (1997). Perkembangan anak jilid 1. Jakarta: PENERBIT ERLANGGA.

ILO. (2016). Inklusi Penyandang Disabilitas Di Indonesia. Dipetik 10 21, 2018, dari www.ilo.org/jakarta

Kawanto, F. H. (2010). Factors Associated with Intellegences in Down Syndrome . Pediatrica Indonesiana , 194-199.

Malik, Z. D. (2014). Meningkatkan Potensi Gerak Dasar Anak Tunadaksa Ringan Melalui Pendekatan Bermain. JRR, JPOK FKIP Universitas Sebelas Maret , 40.

Meggitt, C. (2013). Memahami Perkembangan Anak. Jakarta: Indeks.

Murti, T. (2018). Perkembangan Fisik Motorik dan Perseptual serta Implikasinya pada Pembelajaran di Sekolah Dasar. jurnal Universitas Malang , 24.

Nadia Uswatun Hasanah, H. W. (2014). Pola Asuh Orang Tua Dalam Upaya Pembentukan Kemandirian Anak Down Syndrome. SOCIAL WORK JURNAL .

Rina, A. P. (2016). Meningkatkan Life Skill pada Anak Down Syndrome dengan Teknik Modelling. Persona, Jurnal Psikologi Indonesia , 215-216.

Selikowitz, M. (2001). mengenal sindroma down. jakarta: PT.Archan.

Sugiyono. (2012). Metode Penelitian Kualitatif, Kuantitati, dan R\&D. Bandung: Alfabeta.

Sukmadinata, N. S. (2006). Metode Penelitian Pendidikan . Bandung: PT.Remaja Rosdakarya.

Suyadi, M. U. (2013). Konsep Dasar PAUD. Bandung: PT Remaja Rosdakarya .

Suyatno, S. (2005). Dasar-Dasar Pendidikan Anak Usia Dini. Yogyakarta: Hikayat Publishing.

Upton, P. (2012). Psikologi Perkembangan. Jakarta: Erlangga.

Yusuf, S. (2014). Psikologi Perkembangan Anak dan Remaja. Bandung: PT Remaja Rosdakarya. 